Ю.О. Кібукевич

\title{
ПОРІВНЯЛЬНИЙ АНАЛІЗ ПОКАЗНИКІВ NDVI ДЛЯ РІЗНОЧАСОВИХ ОПТИЧНИХ ТА РАДАРНИХ ЗОБРАЖЕНЬ
}

Анотація. Зміни кліматичних умов на планеті суттєво ускладнюють ведення сільського господарства. Це призводить до зниження продовольчої безпеки по всьому світу. Ефективним рішенням $\epsilon$ застосування космічних технологій, що дозволяють проводити супутниковий моніторинг стану с/2 рослин та вирішити важливі агротехнічні задачі. Сучасні дослідження підтвердили, що для моніторингу полів необхідні рішення, які дозволять уникнути впливу хмарності на побудову часових рядів. У роботі проведено порівняльний аналіз показників нормалізованого відносного вегетаційного індексу (NDVI) для різночасових оптичних та радарних зображень зі супутників Landsat-8, Sentinel-1 ma Sentinel-2 та визначено залежність стану озимої пшениці від кількості опадів. Дослідження були проведені на 5 ділянках площею 209 га з озимою пшеницею. у роботі було виявлено найвищу кореляцію між показниками NDVI, які отримані за допомогою радарного супутника Sentinel-1, та показниками кількості опадів. Проведені дослідження показали, що супутниковий моніторинг полів за допомогою радарної зйомки $\epsilon$ більш ефективним за оптичну зйомку.

Ключові слова: супутниковий моніторинг полів, озима пшениця, радарні дані, оптичні дані, Landsat-8, Sentinel-2, Sentinel-1, NDVI, коефіцієнт детермінації, R2.

Постановка проблеми. Зміни кліматичних умов на планеті, такі як аномальна спека, повені, лісові та торф'яні пожежі, суховії, ожеледі, суттєво ускладнюють ведення сільського господарства. Виснаження ресурсів сільськогосподарських земель та погіршення стану сільськогосподарських культур призводить до зниження продовольчої безпеки по всьому світу. Ефективним рішенням підвищення продуктивності аграрних робіт та урожайності $\epsilon$ застосування космічних технологій, які забезпечують спостереження за станом сільгоспугідь будь-якого розміру та місця розташування. Супутниковий моніторинг дозволяє вирішити задачі картографування сільськогосподарських угідь, визначити стан грунту та насаджень на різних стадіях розвитку, вчасно

(C) Кібукевич Ю.О., 2021 


\section{«Системні технології» 5 (136) 2021 «System technologies»}

виявити процеси потенційної загрози урожаю, спрогнозувати погодні умови, планувати агротехнічні роботи та ін.

Аналіз останніх досліджень і публікацій. Для оцінки стану рослин, наявності хвороб, а також для прогнозування врожайності полів досліджується декілька основних показників вегетаційних індексів (NDVI, LAI, EVI). У роботі [1] метою дослідження було оцінити вплив опадів на рослинність та порівняти показники NDVI та індекс радіолокаційної вегетації (RVI). Порівняння двох індексів рослинності показало, що індекс NDVI із загальною точністю понад 70\% має найбільшу здатність відокремлювати напівгусті ліси від густих. Однак індекс RVI є більш ефективним для відокремлення рідких лісів. Метою роботи [2] було отримання NDVI безхмарного продукту (NDVInc) шляхом моделювання Sentinel-2 NDVI з використанням різних методів регресії та зворотного розсіювання радіолокатора Sentinel-1. Отримані дані дозволяють 3 великою достовірністю моделювати NDVI сільськогосподарських культур протягом усього фенологічного циклу. У роботі [3] результати дослідження показали, що RVI бути ефективно використаний для моніторингу полів сої та бавовни, а також може бути використаний для контролю вологості грунту. У роботі [5] використовуються дані радарного супутника Sentinel-1 та оптичні зображення супутника Landsat-8 протягом чотирьох сезонів, щоб виявити взаємозв'язок між інтерферометричною когерентністю та NDVI на п'яти ділянках, що мають деформацію грунту внаслідок гірничих робіт. Дослідження показало, що значення інтерферометричної когерентності можна використовувати для виявлення густоти рослинності, тоді як значення NDVI можуть бути еталонними для з'ясування, коли можна ефективно використовувати традиційний диференціальний інтерферометричний радар із синтетичною апертурою (DInSAR). Проведені дослідження підтвердили, що для моніторингу полів необхідні рішення, які дозволять уникнути проблем, пов’язаних з високою хмарністю.

Метою дослідження $є$ порівняльний аналіз показників нормалізованого відносного вегетаційного індексу (NDVI) для різночасових оптичних та радарних зображень зі супутників Landsat-8, Sentinel-1 та Sentinel-2 та визначення залежності стану озимої пшениці від кількості опадів.

Викладення основного матеріалу дослідження. У роботі досліджуються сільськогосподарські ділянки загальною площею більш ніж 850 га, які розташовані у дослідному господарстві у Дніпропетровській області, Україна (рис.1). 
«Системні технологіï» 5 (136) 2021 «System technologies»

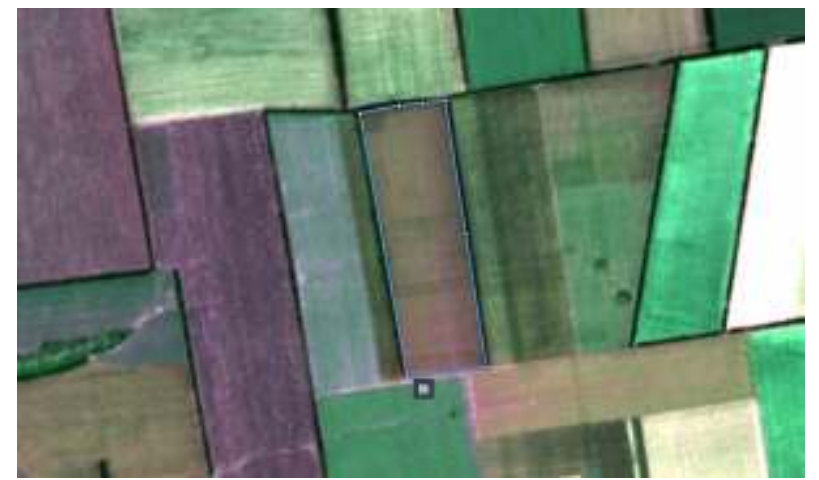

Рисунок 1 - Супутникове зображення із векторним шаром дослідної ділянки з озимою пшеницею

У районі помірно континентальний клімат. Середня температура січня становить від $-5{ }^{\circ} \mathrm{C}$ до $-6,5{ }^{\circ} \mathrm{C}$; липня - від $+23,5{ }^{\circ} \mathrm{C}$ до $+22{ }^{\circ} \mathrm{C}$. Середні опади в районі складають 400 мм. Основними культурами, які вирощуються, є озима пшениця, кукурудза, рапс та інші. Для дослідження відібрано 5 ділянок площею 209 га з озимою пшеницею, оскільки ця культура є найбільш залежною від погодних умов.

У роботі дослідження проводились за допомогою різночасових космічних зображень, отриманих зі супутників Landsat-8, Sentinel-1 та Sentinel-2. Часовий період супутникового моніторингу - з серпня по січень 2018 року.

Для первинних зображень було проведено геометричну та радіометричну корекцію для встановлення відповідностей та видалення помилок [7].

Нормалізований відносний вегетативний індекс (NDVI) - один із основних показників змін рослинності. Розраховується за формулою:

$$
N D V I=\frac{N I R-R}{N I R+R}
$$

де NIR - ближній інфрачервоний канал, R - червоний канал.

Для радарних даних NDVI розраховується за формулою:

$$
N D V I=\frac{V H-V V}{V H+V V},
$$

де VH та VV поляризації зворотного розсіювання. Діапазон значень NDVI різниться від -1 до +1 . Коли рослинність має високу щільність, цей показник ближче до +1, а у разі знищення або захворювання рослинності він зменшується до 0. Значення вегетаційного індексу NDVI для оптичних та радарних зображень наведені на рисунку 2. 
«Системні технології» 5 (136) 2021 «System technologies»

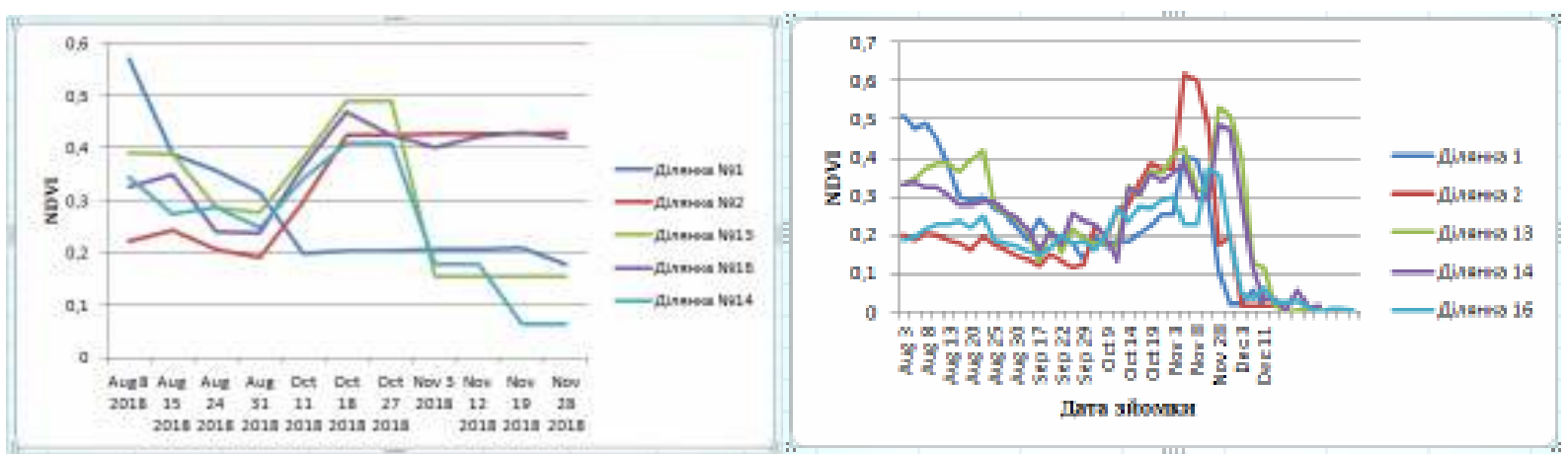

a)

б)

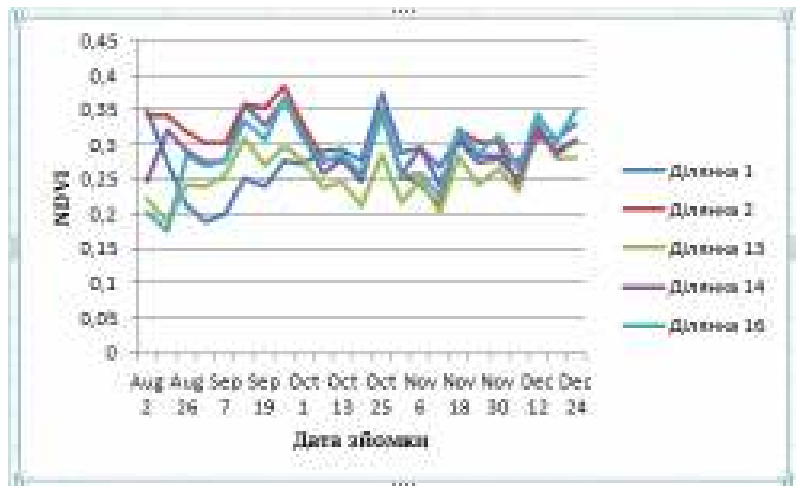

B)

Рисунок 2 - Часові ряди NDVI, отримані з супутникових зображень, з серпня по січень у 2018 році для кожної дослідної ділянки:

а) Landsat-8; б) Sentinel-2; в) Sentinel-1.

Посів озимих зернових найчастіше відбувається у вересні-жовтні місяці. Саме тому побудовано часовий ряд вегетаційного індексу NDVI з серпня 2018 по січень 2018.

Для визначення залежності стану рослин від кількості опадів у роботі було розраховано коефіцієнт детермінації (R2). Формула розрахунку:

$$
R^{2}=\frac{\left[\sum_{i=1}^{n}\left(P_{i}-\bar{P}\right)\left(O_{i}-\bar{O}\right)\right]^{2}}{\left[\sum_{i=1}^{n}\left(P_{i}-\bar{P}\right)^{2}\right]\left[\sum_{i=1}^{n}\left(O_{i}-\bar{O}\right)^{2}\right]},
$$

де Pi - кількість осадів, Oі - значення NDVI, $\bar{O}$ - середнє значення, $\mathrm{n}$ кількість пар даних.

Висновки. В залежності від сезону та погодних умов відрізняється відбивна здатність рослин, що призводить до змін показників вегетаційних індексів. Для оцінки стану та здоров’я сільськогосподарських культур варто враховувати кількість опадів, температуру повітря та вологість грунтів. У роботі було виявлено найвищу кореляцію між показниками NDVI, які отримані 


\section{«Системні технологіï» 5 (136) 2021 «System technologies»}

за допомогою радарного супутника Sentinel-1, та показниками кількості опадів. Коефіцієнт детермінації для радарних зображень Sentinel-1 дорівнює $25,65 \%$, для оптичних зображень - 11,49\%. Внаслідок того, що зображення зі супутника Landsat-8 мають просторову роздільну здатність в 2 рази менше ніж зі супутників Sentinel-1-2, кореляція між показниками $є$ мінімальною. Проведені дослідження показали, що супутниковий моніторинг полів за допомогою радарної зйомки є більш ефективним за оптичну зйомку.

\section{REFERENCES}

1. S.Yaghobi Comparing NDVI and RVI for forest density estimation and their relationships withrainfall (Case study:Malekshahi,Ilam Province)/ Yaghobi S., Heidarizadi Z., Mirzapour H.//Environmental Resources Research.-Vol.7,No.2, 2019. 2. Roberto Filgueiras. Crop NDVI Monitoring Based on Sentinel 1/Roberto Filgueiras, Everardo Chartuni Mantovani, Daniel Althoff, Elpídio Inácio Fernandes Filho, Fernando França da Cunha//Remote Sens. -11, 1441, 2019.

3. Dinesh Kumar. Radar Vegetation Index as an Alternative to NDVI for Monitoring of Soyabean and Cotton/Dinesh Kumar, Srinivasa Rao and Jaswant RAJ Sharma.// Indian Cartographer. - Vol. XXXIII, 2013.

4. Violeta Poenaru. Multi-temporal multi-spectral and radar remote sensing for agricultural monitoring in the Braila Plain/Violeta Poenaru, Alexandru Badea, Sorin Mihai Cimpeanu, Anisoara Irimescu.// Agriculture and Agricultural Science Procedia 6 - 506 - 516, 2015.

5. Alejandro Mestre-Quereda. Time-Series of Sentinel-1 Interferometric Coherence and Backscatter for Crop-Type Mapping/Alejandro Mestre-Quereda, Juan M. LopezSanchez, Fernando Vicente-Guijalba, Alexander W. Jacob, Marcus E. Engdahl// IEEE Journal of Selected Topics in Applied Earth Observations and Remote Sensing - Vol. 13, 4070 - 4084, 2020.

6. Zechao Bai. Could Vegetation Index be Derive from Synthetic Aperture Radar? The Linear Relationship between Interferometric Coherence and NDVI / Zechao Bai , Shibo Fang, Jian Gao, Yuan Zhang, Guowang Jin, Shuqing Wang, Yongchao Zhu \& Jiaxin Xu// Scientific Reports - volume 10, Article number: 6749, 2020.

7. Olena Kavats. Flood Monitoring Using Multi-Temporal Synthetic Aperture Radar Images/ Olena Kavats, Volodymyr Hnatushenko, Yuliya Kibukevych, Yurii Kavats// CSIT2019, 046, v3.

Received 29.03.2021. Accepted 24.04.2021.

\section{Сравнительный анализ показателей NDVI}

\section{для разновременных оптических и радарных изображений}

B работе проведен сравнительный анализ показателей NDVI для разновременных оптических и радарных изображений со спутников Landsat-8, 


\section{«Системні технологіï» 5 (136) 2021 «System technologies»}

Sentinel-1 и Sentinel-2 и определена зависимость состояния озимой пшеницы от количества осадков. Исследования были проведены на участках с озимой пшеницей. В работе было выявлено самую высокую корреляцию между показателями NDVI, полученные с помощью радарного спутника Sentinel-1, u показателями количества осадков. Проведенные исследования показали, что спутниковый мониторинг полей с помощью радарной съемки является более эффективным, чем оптическая съемка.

\section{Comparative analysis of NDVI for optical and radar images}

Climate change on the planet, such as abnormal heat, floods, forest and peat fires, dry winds, ice, significantly complicates agriculture and reduces worldwide food safety.. An effective solution is to use of space technologies. It allows to solve important agricultural problems, such as mapping of agricultural lands, determination the condition of soil and plantations at different stages of development, detection in time the processes of potential threat to the crop, forecasting weather conditions, planning agro-technical works and carry out satellite monitoring of agricultural plants.

In modern works several main indicators of vegetation indices (NDVI, LAI, EVI) are studied to assess the condition of plants, the presence of diseases, as well as to predict the yield of crops.Modern researches have confirmed that crop monitoring requires solutions that avoid the effects of cloudiness on time series construction.

In this work we compared the Normalized Difference Vegetation Index (NDVI) for different-time optical and radar images from Landsat-8, Sentinel-1 and Sentinel-2 satellites and determined the dependence of winter wheat on precipitation. The study was carried out on 5 plots with an area of 209 hectares with winter wheat, which are located in the in Dnipropetrovsk region, Ukraine. The time period for satellite monitoring is from August to January 2018.

To assess the condition and health of crops it should be taken into account values of precipitation, air temperature and soil moisture. In this work we found the highest correlation between NDVI values obtained with the radar satellite Sentinel-1 and precipitation values. The coefficient of determination for radar images Sentinel-1 is $25.65 \%$, for optical images - 11.49\%.This research shown that satellite crop monitoring with radar imaging is more effective than optical imaging.

Кібукевич Юлія Олегівна - аспірант кафедри інформаційних технологій і систем Національної металургійної академії України (м. Дніпро).

Кибукевич Юлия Олеговна - аспирант кафедры информационных технологий и систем Национальной металлургической академии Украины (г. Днепр).

Kibukevych Iuliia - graduate student of the Department of Information Technologies and Systems of the National Metallurgical Academy of Ukraine. 